\title{
Klient jako współtwórca wartości w społecznościach sieciowych
}

\section{Wstęp}

Pojęcie media społecznościowe jest obecnie, ze względu na swoją wielowymiarowość, jak i charakter podlegający ciągłym zmianom, różnorodnie interpretowane. Bez względu jednak na to, czy mówimy o mediach społecznościowych czy wirtualnych społecznościach klientów, coraz więcej firm staje przed obliczem decyzji o adaptacji tych rozwiązań $w$ ramach realizowanych przez siebie strategii, upatrując coraz więcej korzyści płynących z partycypacji w wirtualnym środowisku. Na szczególną uwagę zasługują tu zagadnienia związane z potencjałem kreowania wartości nie tylko przez same media społecznościowe, ale w szczególności przez konsumentów będących ich uczestnikami. Ich rola w procesie współtworzenia wartości w organizacji staje się obecnie szczególnie istotnym i wartym przybliżenia zagadnieniem.

W artykule zawarta jest próba wskazania potencjału mediów społecznościowych w generowaniu wartości dla organizacji oraz charakterystyka roli, jaką w tym procesie odgrywają obecni i potencjalni klienci, uczestnicy wirtualnych społeczności.

\section{Media społecznościowe jako nowy kierunek działań organizacji}

Szereg odniesień nawiązujących do samego słowa media może rodzić pokusę ulokowania mediów społecznościowych jako kolejnego, obok radia, telewizji czy prasy, kanału komunikacji. Należy jednak pamiętać, iż są to kanały o jednokierunkowym przepływie komunikatu, tymczasem, jak postuluje Scott Stratten, istotą mediów społecznościowych jest dialog z podmiotami rynkowymi, obejmujący klientów, współpracowników oraz wszelkie osoby, które chcą wziąć udział w dyskusji¹.

${ }^{1}$ S. Stratten, BezMarketing. Przestań kusić klientów, zacznij z nimi rozmawiać!, Helion, Warszawa 2012, s. 33. 
Podobne podejście prezentuje Merchant, wskazując na główne determinanty mediów społecznościowych, wśród których jako najistotniejsze wymienia wspólnotę, współpracę i współtworzenie ${ }^{2}$. Wskazuje jednocześnie, że głównym źródłem generowania wartości w tych mediach stają się połączenia, czy inaczej sieci, powiązanych ze sobą wspólnymi zainteresowaniami czy też celami użytkowników.

Media społecznościowe stanowią obecnie istotny element kreowania wizerunku i obecności marek na rynku, bez względu na fakt, czy marki te zarządzają swoim udziałem w wirtualnych społecznościach czy też dzieje się to bez ich udziału i zaangażowania. Organizacje, które świadomie podejmują decyzję dotyczącą budowania wizerunku z wykorzystaniem mediów społecznościowych, napotykają szereg wyzwań, którym muszą sprostać.

Obok wątpliwości, czy obecność organizacji i podejmowanie tego rodzaju aktywności jest w ogóle zasadne, menedżerowie często stają w obliczu pytań, powstających wewnątrz przedsiębiorstwa, o efektywność przedsięwzięć (ROI) oraz ich wpływ na wartość firmy. O ile w przypadku dóbr materialnych dobór miar oraz raportowanie efektów podejmowanych działań stanowią niewielkie wyzwanie dla współczesnych menedżerów, o tyle efektywność w obszarze wartości marki, satysfakcji klienta czy lojalności zdecydowanie trudniej zmierzyć.

Odmiennym, choć nie mniej istotnym, aspektem jest charakter samego udziału marki w mediach społecznościowych. Organizacja może podjąć decyzję o tworzeniu wirtualnej społeczności wokół własnej marki bądź wirtualne społeczności mogą powstawać same, bez udziału i wsparcia ze strony firmy. Oba te przypadki różnią się z uwagi na swą odmienność w wielu obszarach, bez wątpienia jednak, w każdym z nich, elementem wspólnym jest niezaprzeczalny wpływ zarówno na wizerunek marki, jak i wartość samej firmy.

Ponad $80 \%$ firm z listy Fortune 500 wykorzystuje, w różnym stopniu, media społecznościowe, jednak sam fakt ,polubienia” strony czy obecności marki w mediach społecznościowych niekoniecznie przekłada się na znaczące rezultaty $^{3}$. Interesująco przedstawia się również problem transparentności środowiska online, zwłaszcza w aspekcie identyfikacji członków społeczności wspierających czy gromadzących się wokół marek.

Badania zrealizowane przez Naylor, Lamberton i West ujawniły, że transparentność w takich przypadkach może mieć negatywne skutki dla marki, szczegól-

${ }^{2}$ N. Merchant, 11 Rules for Creating Value in the Social Era, „Harvard Business Review Press" 2012.

${ }^{3}$ R. Naylor, W.C.P. Lamberton, P.M. West, Beyond the "Like" Button: The Impact of Mere Virtual Presence on Brand Evaluations and Purchase Intentions in Social Media Settings, „Journal of Marketing" 2012, vol. 76, s. 105. 
nie w odniesieniu do społeczności, która stanowi homogeniczną grupę, znacząco różniącą się od docelowej grupy konsumentów danej firmy ${ }^{4}$. Może mieć to istotne znaczenie gdy firma decyduje się skierować swoją ofertę na nowy rynek docelowy. W takiej sytuacji zdecydowanie bardziej bezpieczne, jak rekomendują autorzy badania, będzie nieujawnianie tożsamości członków społeczności.

Media społecznościowe, a w szczególności ich obecna popularność, dzięki połączeniu nowoczesnych technologii oraz naturalnej potrzeby człowieka związanej z przynależnością do grupy, stwarzają dzisiaj niespotykane wcześniej na taką skalę i w takim zakresie, możliwości budowania relacji pomiędzy firmą a jej konsumentami. Relacje te mogą być również źródłem generowania wartości przez wszystkie podmioty wirtualnej społeczności, a w konsekwencji stać się satysfakcjonujące i korzystne dla wszystkich uczestników rynku.

Globalny dialog, przejrzystość, nieograniczony dostęp do informacji oraz tempo jej powstawania i upowszechniania jak nigdy dotąd wzmacniają pozycję konsumenta. Organizacje muszą zatem podejmować szereg starań, aby sprostać oczekiwaniom i wymaganiom współczesnych konsumentów. Z drugiej strony, dzięki naturalnej skłonności do dzielenia się, współpracy i współtworzenia, firmy stają przed ogromną szansą wykorzystania potencjału klientów do generowania wartości. Coraz częściej zatem włączają się w dialog z klientami i sięgają po rozwiązania społecznościowe dostępne i popularne w Internecie.

\section{Wolontariat konsumencki w obszarze generowania wartości}

Wartość jest obecnie powszechnie uznawaną zmienną definiującą organizację i jej ofertę na rynku. Według definicji Amerykańskiego Stowarzyszenia Marketingu (American Marketing Association), „marketing jest zbiorem procesów realizowanych w celu kreowania, komunikowania, dostarczania i wymiany ofert posiadających wartość dla konsumentów, klientów, partnerów i całego społeczeństwa" ". Peter Doyle w swojej książce Marketing wartości definiuje natomiast marketing jako „proces zarządczy ukierunkowany na maksymalizację zwrotów dla udziałowców poprzez wdrażanie strategii mających na celu budowanie opartych na zaufaniu relacji z wartościowymi klientami oraz tworzenie trwałej przewagi różnicującej”.

\footnotetext{
${ }^{4}$ Ibidem.

${ }^{5}$ http://www.marketingpower.com/AboutAMA/Pages/DefinitionofMarketing.aspx [dostęp 10.10.2013].

${ }^{6}$ P. Doyle, Marketing wartości, Felberg SJA, Warszawa 2003, s. 84.
} 
„Społeczność” definiowana jako funkcja może być zaadaptowana niemal do wszystkich technologii związanych z interakcją pomiędzy ludźmi i charakteryzuje się prawie nieograniczoną możliwością zastosowań. Technologie społecznościowe umożliwiają przeniesienie relacji i interakcji pomiędzy członkami społeczności do środowiska Internetu, uwalniając wszystkich uczestników wirtualnej społeczności od tradycyjnych ograniczeń realnego świata, takich jak geograficzna odległość, strefy czasowe oraz zasięg, tj. możliwość dotarcia i wywierania wpływu na znacznie większą liczbę ludzi.

Zagadnienia związane z generowaniem wartości przez klientów są przedmiotem analizy wśród badaczy tematu od dawna ${ }^{7}$. Jednak dzięki upowszechnieniu się mediów społecznościowych, klienci postrzegani są już nie tylko jako partnerzy, ale coraz częściej jako źródło generowania wartości oraz przewagi konkurencyjnej ${ }^{8}$.

Współtworzenie wartości obejmuje dzisiaj nie tylko firmę, ale również jej udziałowców zarówno wewnętrznych, jak i zewnętrznych. Wspólne tworzenie oparte na różnorodnych doświadczeniach podmiotów biorących udział w procesie, pozwala uzyskać nowe spojrzenie na różne aspekty przedmiotu czy zagadnienia podlegającego analizie, prowadzące często do redukcji ryzyka, większej produktywności czy innowacyjności bądź finalnie wyższych zysków9.

Przykładowo w 2008 roku, firma Starbucks zdecydowała się udostępnić swoim klientom platformę MyStarbucksIdea.com w celu zaangażowania konsumentów do generowania nowych pomysłów, które byłyby źródłem wartości zarówno dla nich samych, jak i dla organizacji. Do końca roku zgłoszono 65000 pomysłów, na które konsumenci oddali 658000 głosów. Spośród zgłoszonych pomysłów wybrano i zaimplementowano 58 , które przyczyniły się do poprawy kondycji finansowej firmy ${ }^{10}$. Sukces podjętych działań wynikał nie tylko z zaangażowania klientów, ale również wybranych pracowników, nazwanych „Idea Partners”, którzy podejmowali dyskusje z klientami i jednocześnie omawiali zgłaszane projekty w organizacji ${ }^{11}$.

Włączanie klientów w działalność firm w wielu obszarach nie jest niczym nowym. Przykładowo w branży oprogramowania wiele firm powszechnie od lat korzysta z procesu testowania produktów, nie we własnych laboratoriach, a z wykorzystaniem tak zwanych beta testerów, czyli obecnych klientów zaproszonych

${ }^{7}$ C.K. Prahalad, V. Ramaswamy, Co-Opting Customer Competence, „Harvard Business Review" 2000, January-February.

${ }^{8}$ N. Merchant, op. cit.

${ }^{9}$ L.M. Frigo, How Enterprises Can Drive New Value Creation, „Strategic Finanse” 2010, October, s. 17.

${ }^{10}$ Ibidem.

${ }^{11}$ Ibidem. 
do udziału w procesie. Wersja beta Windows 2000 Microsoftu była testowana przez ponad 650000 klientów, a wartość ich prac, odnosząca się do poświęconego czasu, podejmowanych wysiłków czy wysokości wynagrodzeń, którą trzeba byłoby wypłacić pracownikom działu badań i rozwoju, została oszacowana na ponad 5 miliardów dolarów ${ }^{12}$. Uczestnicząc w tym zadaniu, klienci nie tylko weryfikowali poprawność działania systemu i mieli możliwość zgłaszania pożądanych przez siebie ulepszeń. Firma wykorzystała ten zabieg również jako możliwość zapoznania potencjalnych nabywców z produktem i dostrzeżenia, w jaki sposób mogą kreować wartość w swoim własnym biznesie.

Prahalad i Ramaswamy już w 1999 roku zauważyli kilka istotnych czynników, które wpływają na możliwość wykorzystania potencjału klientów, generującą wartość dla organizacji ${ }^{13}$. Wskazali w szczególności na:

- zachęcanie do aktywnego dialogu opartego na zasadach równości,

- mobilizowanie społeczności klientów,

- zarządzanie różnorodnością klientów,

- współtworzenie osobistych doświadczeń.

O ile korzyści dla organizacji wydają się oczywiste i wymierne na wielu płaszczyznach, o tyle rozstrzygnięcie, jakimi pobudkami kierują się konsumenci jest nie tylko interesujące, ale przede wszystkim może przynieść odpowiedź na pytanie o stabilność modeli biznesowych opartych na partycypacji konsumentów czy, idąc dalej, o prawo własności marek i prawa autorskie do zgłaszanych pomysłów, za które powinno przysługiwać wynagrodzenie. Z drugiej strony zrozumienie motywacji klientów pozwoli na lepszą optymalizację rozwiązań, dedykowanych konsumentom do wspólnego podejmowania działań nad kreowaniem wartości.

Jednak wiele firm nadal przyjmuje, że konsumenci angażują się wyłącznie dobrowolnie, nie oczekując żadnych korzyści. Decydują się na ustanowienie platformy wymiany doświadczeń pomiędzy klientami, z założeniem, że ,jeśli udostępnimy miejsce, pojawią się klienci"14.

Badania przeprowadzone przez Nambisan i Baron wskazują jednak, że klienci oczekują korzyści, a ich działania nie są do końca bezinteresowne. Ich aktywny udział w platformach wspierających proces generowania wartości, w dużej mierze wynika z przekonania o potencjalnych korzyściach, których będą beneficjentami,

${ }^{12}$ C.K. Prahalad, V. Ramaswamy, op. cit.

13 Ibidem.

${ }^{14}$ S. Nambisan, A.R. Baron, Virtual Customer Environments: Testing a Model of Voluntary Participation in Value Co-creation Activities, „The Journal of Product Innovation Management” 2009, vol. 26, s. 402. 
wśród których autorzy badania wymieniają dostęp do informacji o produkcie, członkostwo w społeczności oraz interaktywność ${ }^{15}$.

Należy również zauważyć, na co zwracają uwagę autorzy i co również znajduje swoje potwierdzenie w przytoczonym przykładzie Starbucsa, że po stronie organizacji, niezwykle istotną kwestią, warunkującą zaspokojenie tych potrzeb, jest powołanie odpowiednich pracowników skierowanych do prowadzenia działań w tym zakresie czy wręcz całych działów odpowiedzialnych za proces kreowania wartości wspólnie z konsumentami.

Obecnie największe przedsiębiorstwa, takie jak Apple, Nestle, Lego czy Orange z sukcesem wdrażają strategie współpracy z klientami w ramach kreowania wartości ${ }^{16}$. Wiele firm stoi jednak przed licznymi wyzwaniami związanymi ze skuteczną adaptacją poszczególnych rozwiązań społecznościowych, które umożliwią im w dłuższej perspektywie skuteczną komunikację i współpracę z klientami.

\section{Etapy adaptacji rozwiązań społecznościowych}

Altimer Group wyróżnił sześć faz dojrzałości organizacji w stosowaniu rozwiązań społecznościowych w obszarze biznesowym ${ }^{17}$. Każdy ze zidentyfikowanych etapów charakteryzuje się odmiennymi korzyściami, ale również określonym ryzykiem. Strategia mediów społecznościowych w wielu przypadkach odnosi się głównie do kanałów, platform i taktyki działania umożliwiających organizacjom publikowanie własnych informacji, wsłuchiwanie się w głos konsumentów, finalnie zmierzających do budowy zaangażowania. Strategia biznesu społecznościowego odnosi się zaś do integracji/włączenia technologii i procesów społecznościowych w wartości biznesowe i podejmowane działania, których głównym celem jest budowanie relacji oraz podejmowanie dialogu przenikającego granice organizacji, angażującego zarówno klientów, jak i pracowników, oraz wspólne kreowanie wartości dla klientów, a także organizacji. Wiąże się to z koniecznością wpisania działań w obszarze mediów społecznościowych w kontekst biznesowy i w jasno zdefiniowane cele biznesowe całej organizacji.

${ }^{15}$ Ibidem.

${ }^{16}$ V. Ramasvamy, F. Goillart, The Power of Co-creation, Free Press, Simon \& Schuster Inc, New York 2010.

${ }^{17}$ Ch. Li, B. Solis, A. Webber, J. Szymanski, The Evolution of Social Business, Six Stages of Social Business Transformation, Altimeter Group Network on SlideShare, San Mateo 2013. 
Pełna integracja/włączenie mediów społecznościowych w strategię biznesową organizacji wymaga jednak podejmowania określonych, stopniowych działań, które składają się na konkretne fazy, czy inaczej etapy, przez które muszą przejść wszystkie organizacje. Firmy podejmujące działania z wykorzystaniem mediów społecznościowych powinny rozpocząć swoją aktywność od etapu planowania, opartego głównie na monitoringu zachowań konsumentów, w odniesieniu do własnej marki, w różnorodnych kanałach czy platformach komunikacyjnych.

Etap ten polega głównie na zrozumieniu klientów, tego o czym mówią, w jaki sposób wykorzystują media społecznościowe i czym charakteryzują się ich działania. Etap ten został nazwany "słuchaniem w celu nauki” (listen to learn). Dave Kerpen podkreśla, że dzisiejsza komunikacja składa się w 50\% z mówienia i w $50 \%$ ze słuchania ${ }^{18}$.

Etap słuchania to rozpoznawanie potrzeb klientów i, w kolejnym kroku, realizacja projektów pilotażowych z wykorzystaniem różnorodnych platform i rozwiązań społecznościowych, w celu rozpoznania działań o największym wpływie na zdefiniowane wcześniej cele biznesowe. $Z$ równą uwagą powinniśmy obserwować konkurencję oraz nowe projekty mediów społecznościowych pojawiające się na rynku ${ }^{19}$.

Zdiagnozowanie najbardziej efektywnych obszarów działania prowadzi w konsekwencji do kolejnego etapu, w którym organizacje ustanawiają swoją obecność w mediach społecznościowych. Wymaga to nie tylko uruchomienia odpowiednich zasobów organizacji, ale przede wszystkim wypracowania i przyjęcia całościowej strategii zarządzania treściami publikowanymi w Internecie, które wpisują się w zintegrowaną strategię komunikacji przedsiębiorstwa. Na szczególną uwagę zasługuje obecna praktyka wpisywania działań społecznościowych w już przyjętą i funkcjonującą strategię komunikacji, traktującą obecność w mediach społecznościowych jako kolejny element wspierający i dodatkowy kanał komunikacji ${ }^{20}$. W znacznej mierze wynika to z implementacji koncepcji mediów społecznościowych w już istniejące reguły i procedury, które zostały ustanowione i zaakceptowane przez władze firmy ${ }^{21}$.

${ }^{18}$ D. Kerpen, Likeable Social Media: How to Delight Your Customers, Create an Irresistible Brand, and Be Generally Amazing on Facebook (\& Other Social Networks), McGraw-Hill, New York 2011.

${ }_{19}$ A.J. Bradley, M.P. McDonald, The Social Organization - How to Use Social Media to Tap the Collective Genius of Your Customers and Employees, Gartner, Inc., „Harvard Business Review Press" 2011, October.

${ }^{20}$ Ch. Li, B. Solis, A. Webber, J. Szymanski, op. cit.

${ }^{21}$ A.J. Bradley, M.P. McDonald, op. cit. 
Należy sobie jednak zadać pytanie, czy takie podejście i ten kierunek działania są rozwiązaniem prawidłowym i najbardziej efektywnym. Nie wykorzystują one bowiem mediów społecznościowych ze wszystkimi ich możliwościami, począwszy od podejmowania dialogu po zaawansowaną współpracę z klientami. Sprowadzają się w głównej mierze do wysyłania komunikatów marketingowych firmy. Z drugiej jednak strony podejmowanie działań w obszarze, w którym organizacja nie czuje się jeszcze dostatecznie pewnie, może być również ryzykowne. Minimalizacja ryzyka może być w takim przypadku oparta na komunikacji jednostronnej, wpisującej się całkowicie w strategię komunikacji firmy i uwzględniającej czas na uczenie się.

Trzeci etap zaawansowania w stosowaniu mediów społecznościowych odnosi się w głównej mierze do zaangażowania (engagement) w budowanie, którego głównym narzędziem stosowanym przez firmy jest dialog służący budowaniu relacji ${ }^{22}$. Według Kerpena, zaangażowanie oznacza prawdziwe i szczere zainteresowanie tym, co klienci i potencjalni klienci firmy maja do przekazania ${ }^{23}$. Firma przechodzi z etapu, w którym cechą charakterystyczną jest przeświadczenie o konieczności posiadania mediów społecznościowych, do etapu, w którym uświadamia sobie, że warto wykorzystać tę obecność w celu pogłębienia relacji z obecnymi i potencjalnymi klientami. Znaczna część firm obawia się na tym etapie negatywnych komentarzy czy wręcz braku zainteresowania ze strony klientów. Warto jednak uświadomić sobie, że etap ten umożliwia firmom wywarcie wpływu na różnorodne aspekty, takie jak budowanie społeczności, generowanie wartości poprzez treści o wysokiej merytoryce, kreatywności czy współczynniku udostępnień.

Przy podejmowaniu coraz liczniejszych aktywności w obszarze mediów społęcznościowych i wykorzystywaniu wielu kanałów dotarcia do klienta, takich jak Twitter, Facebook, Google+ czy blogi, zarządzanych często przez różne zespoły czy departamenty w organizacji, bardzo ważną kwestią jest podjęcie wysiłków w celu skoordynowania podejmowanych inicjatyw i przekazywania tych samych wartości $\mathrm{w}$ imieniu organizacji $\mathrm{i}^{24}$. Wymaga to opracowania strategii $\mathrm{i}$ adaptacji jej w całej organizacji. Jednym z głównych założeń takiego opracowania powinno być określenie zarówno zakresu odpowiedzialności, obszarów komunikacji, jak i zdecydowanie, w myśl założeń dotyczących definiowania strategii przedstawionych przez Portera, czego organizacja nie będzie realizować i z jakich kierunków działania rezygnuje.

\footnotetext{
${ }^{22}$ Ch. Li, B. Solis, A. Webber, J. Szymanski, op. cit.

${ }^{23}$ D. Kerpen, op. cit.

${ }^{24}$ Ch. Li, B. Solis, A. Webber, J. Szymanski, op. cit.
} 
$\mathrm{Z}$ uwagi na strategiczny wymiar i znaczenie wymienionego zadania wymaga to pozyskania akceptacji oraz wsparcia ze strony osób zarządzających w organizacji. Istotne jest również ustanowienie centrum organizacyjnego definiowanego przez Altimer jako „Center of Excellence” (CoE), które organizuje i porządkuje rozwój i adaptację strategii społecznościowej, nadzoru, podejmowanych inicjatyw oraz niezbędnych technologii w obszarze całej organizacji ${ }^{25}$. Może ono przybierać różne struktury: od zdecentralizowanych, których stosowanie zadeklarowało w badaniu 9,4\% respondentów, scentralizowane $(29,1 \%)$, hub \& spoke (35,4\%), multiple hub \& spoke $(23,6 \%)$ po holistyczne $(2,4 \% \text { respondentów })^{26}$. Niezwykle istotne jest opracowanie i wybór miar pozwalających na weryfikację działań podejmowanych w mediach społecznościowych i ich wpływu na realizację działań biznesowych. Pozwala to nie tylko na pomiar efektów umożliwiający ciągłe dostosowywanie podejmowanych działań w celu osiągnięcia najlepszych rezultatów, ale również na umacnianie akceptacji podejmowanych działań przez zarząd i organizację, co często ma bezpośredni wpływ na poziom finansowania dalszych aktywności i inicjatyw.

Etap piąty przesuwa organizację do obszaru biznesu społecznościowego ${ }^{27}$, jej działania stają się bardziej widoczne, a zainteresowanie w organizacji wzrasta. Działania społecznościowe zaczynają być adaptowane do wszystkich ról i funkcji w organizacji, umożliwiając generowanie wartości w wielu indywidualnych obszarach, takich jak marketing i komunikacja, doświadczenie klienta, sprzedaż, finanse, zarządzanie zasobami ludzkimi, IT czy logistyką.

\section{Zakończenie}

Wraz ze wzrastającą popularnością mediów społecznościowych powstaje pytanie, czy możliwe jest dokonywanie pomiaru produktywności i wzrostu wirtualnej społeczności, a przede wszystkim zarządzanie nią w procesie kreowania wartości zarówno dla organizacji, jak i konsumenta. Czy współpraca w ramach wirtualnych społeczności niesie ze sobą ryzyko rosnących oczekiwań klientów, związanych z możliwym wynagrodzeniem za kreowanie i dostarczanie wartości? Kto w takim przypadku jest właścicielem innowacji czy marki, a wreszcie, na jakie ryzyko, w obliczu tak postawionych pytań, wystawiona jest organizacja. Pytania te stanowią ważki punkt wyjścia podejmowania badań w tym obszarze zarówno przez organizacje, jak i badaczy przedmiotu.

\footnotetext{
25 Ibidem.

26 Ibidem.

27 Ibidem.
} 


\section{Bibliografia}

Bradley A.J., McDonald M.P., The Social Organization - How to Use Social Media to Tap the Collective Genius of Your Customers and Employees, Gartner, Inc., „Harvard Business Review Press” 2011, October [Kindle Edition]

Divol R., Edelman E., Sarrazin H., Demystifying social media, „McKinsey Quarterly" 2012, April

Doyle P., Marketing wartości, Felberg SJA, Warszawa 2003

Frigo L.M., How Enterprises Can Drive New Value Creation, „Strategic Finanse” 2010, October

Kerpen D., Likeable Social Media: How to Delight Your Customers, Create an Irresistible Brand, and Be Generally Amazing on Facebook (\& Other Social Networks), McGraw-Hill, New York 2011 [Kindle Edition]

Levine R., Locke Ch., Searls D., Weinberger D., The Cluetrain Manifesto, The end of business as usual, Basics Books, New York 2000

Li Ch., Solis B., Webber A., Szymanski J., The Evolution of Social Business, Six Stages of Social Business Transformation, Altimeter Group Network on SlideShare, San Mateo, CA, United States 2013

Merchant N., 11 Rules for Creating Value in the Social Era, „Harvard Business Review Press" 2012

Nambisan S., Baron A.R., Virtual Customer Environments: Testing a Model of Voluntary Participation in Value Co-creation Activities, ,The Journal of Product Innovation Management" 2009, vol. 26

Naylor R.W., Lamberton C.P., West P.M., Beyond the „Like“ Button: The Impact of Mere Virtual Presence on Brand Evaluations and Purchase Intentions in Social Media Settings, „Journal of Marketing” 2012, vol. 76

Prahalad C.K., Ramaswamy V., Co-Opting Customer Competence, „Harvard Business Review" 2000, January-February

Ramasvamy V., Goillart F., The Power of Co-creation, ree Press, Simon \& Schuster Inc, New York 2010

Reichheld F.F., Teal T., Efekt Lojalności. Ukryta siła rozwojowa Twojej firmy, Helion, Warszawa 2007

Stratten S., BezMarketing. Przestań kusić klientów, zacznij z nimi rozmawiać!, Helion, Warszawa 2012

http://www.forbes.pl/artykuly/sekcje/techno/historyczny-moment-facebooka-miliard-uzytkownikow,30541,1

http://www.marketingpower.com/AboutAMA/Pages/DefinitionofMarketing.aspx 